\title{
FABRICATION AND CHARACTERIZATION OF ELECTRODEPOSITED AND MAGNETRON-SPUTTERED THIN FILMS
}

\author{
Z.A. KHAN ${ }^{1}$, P. PASHAEI ${ }^{2}$, R.S. BAJWA ${ }^{1}$, M.H. NAZIR ${ }^{1} \&$ M. CAKMAK ${ }^{2}$ \\ ${ }^{1}$ Sustainable Design Research Center, Faculty of Science \& Technology, Bournemouth University, UK. \\ ${ }^{2}$ Department of Physics, Gazi University Ankara, Turkey.
}

\begin{abstract}
The $\mathrm{MnO}-\mathrm{Zn}$ thin films were fabricated by radio frequency (RF) magnetron sputtering and compared with pulse electrodeposition (PED) $\mathrm{Zn}$ thin films, doped with $\mathrm{MnO}$ and $\mathrm{ZrO}$ nanoparticles. Surface morphology, structural properties, chemical composition and corrosion resistance of these coatings were investigated by using scanning electron microscopy, X-ray diffraction (XRD), energy-dispersive X-ray spectroscopy, 3-D scanning interferometry and environmental chamber. Surface morphology and degree of crystallinity have different behaviours for different deposition methods. Pulse-coated films have polycrystalline structure with high surface roughness $\left(\mathrm{R}_{\mathrm{a}}\right)$, whereas sputtered films are monocrystalline with reduced roughness $\left(\mathrm{R}_{\mathrm{a}}\right)$. Corrosion tests of both RF sputter and PED films revealed that the distribution of corrosion products formed on the surface of sputter films were not severe in extent as in case of electrodeposited coatings. Results showed that the doping of $\mathrm{ZrO}$ nano-sized particles in $\mathrm{Zn}$ matrix and $\mathrm{Mn}-\mathrm{Zn}$ composite films significantly improved the corrosion resistance of PED thin films. Keywords: Corrosion resistance, electro-deposition, magnetron sputtering, surface analysis, thin films.
\end{abstract}

\section{INTRODUCTION}

Zinc oxide $(\mathrm{ZnO})$ thin films are widely used in variety of applications such as thin-film transistor [1], transparent conducting films, solar cell material [2], UV photodetector [3], piezoelectric [4] and wear-resistant films [5], due to its several favorable properties, including wide bandgap, e.g. -3.37 eV [6], large exciton binding energy (60 meV) [6] and also having good transparency, which are excellent parameters for optoelectronic devices.

High electron mobility [7] and room temperature electrical conductivity of $\mathrm{ZnO}$ thin films make it perfect material for electronics equipment. Additional advantages of $\mathrm{ZnO}$ thin films and micro-nanostructure are abundance and non-toxicity of the $\mathrm{ZnO}$ material, low cast and quantum size effect. Depending on the application, tuning properties and band gap of $\mathrm{ZnO}$ is possible by doping another material such as: aluminum $(\mathrm{Al})$, gallium $(\mathrm{Ga})$, magnesium $(\mathrm{Mg})$ and manganese $(\mathrm{Mn})$.

Also, there are advanced techniques of growing $\mathrm{ZnO}$ thin films and manufacturing such as metal organic chemical vapor deposition [8], radio frequency (RF) magnetron sputtering [9], sol-gel method and pulsed laser deposition [10]. Properties of $\mathrm{ZnO}$ thin films are investigated by using molecular beam epitaxy [11].

Zinc plating is extensively used in corrosion protection of steel in many structural and general engineering applications. Zn coating on steel substrate provides with physical and mechanical properties as well as good corrosion resistance [12]. However, a high dissolution rate and low corrosion resistance limit the use of $\mathrm{Zn}$ coatings. In recent research and development activity on zinc-based alloy coatings, there is a growing interest in the use of $\mathrm{Zn}$ with various alloying elements like $\mathrm{Mn}$ and $\mathrm{Zr}$. These elements ( $\mathrm{Mn}$ and $\mathrm{Zr}$ ) have an electrically, more negative potential $\left(\mathrm{E}_{\mathrm{Mn}}^{\circ}{ }^{2+} / \mathrm{Mn}=-1.185 \mathrm{~V}\right.$ vs. SHE (standard hydrogen electrode) and $\mathrm{E}_{\mathrm{Zr}}^{\circ}{ }^{2+} / \mathrm{Zr}=-1.45 \mathrm{~V}$ vs. SHE) when compared with $\mathrm{Zn}$ [13]. The alloys $\mathrm{Zn}-\mathrm{Mn}, \mathrm{Zn}-\mathrm{Zr}$ and 
$\mathrm{Zn}-\mathrm{Zr}-\mathrm{Mn}$ show an interdependent effect with better corrosion resistance than the individual metals. The need for coatings with improved resistance to highly aggressive environments is high as a result of a growing demand for extended safe service life of industrial objects. Conventional coatings such as spray gun coatings perform well in normal environmental conditions; however, when subjected to aggressive environments result in coating failure due to blistering and delamination. Sputtered and electrodeposited coatings can perform well in aggressive environments and are more resistant to failure due to blistering delamination.

This work is the continuation of current research in materials, structural integrity and coatings [14-21]. This paper presents results, which show that how materials' qualities have been affected by deploying different methods of thin film fabrication. Pulse electrodeposition process is simple with low cost, and deposition can be applied on comparatively larger areas [22]. The RF-magnetron sputtering is a flexible technique in terms of control of composition and microstructure. $\mathrm{Zn}-\mathrm{MnO}$ thin films can be fabricated by reactive RF magnetron sputtering deposition with high-purity $\mathrm{ZnO}$ powder, which results in the formation of films with excellent purity. On the other hand, a vacuum method is a costly procedure and some of scaling process is difficult. Pulse electrodeposition has been widely applied to fabrication of thin films, and results show that the uniformities such as thickness of layer, grain size, roughness and defect density are difficult to control [23].

It is obvious that the properties of $\mathrm{ZnO}$ thin films are extremely sensitive to the sample preparation process, and the focus of this research is to compare chemical and physical deposition techniques. Investigate surface morphology, elemental composition and durability of two different methods of $\mathrm{ZnMnO}$ thin films fabrication. Additionally, the effect of incorporated $\mathrm{MnO}$ and $\mathrm{ZrO}$ nanoparticles on corrosion resistance is also investigated for coatings prepared by two different methods.

\section{EXPERIMENTAL}

\subsection{Preparation of sputtered and electrodeposited coatings}

In this work, $\mathrm{MnO}-\mathrm{Zn}$ thin film was deposited on glass substrate by RF magnetron sputtering method. The required thin films have been achieved by using a mixture of high-purity $\mathrm{ZnO}$ with 36 wt. $\% \mathrm{MnO}_{2}$. Substrate was conditioned carefully by using ethanol and dried by subjecting the samples to flowing $\mathrm{N}_{2}$ gas. The pressure of the chamber was kept as $2.9 \times 10^{-8}$ mbar. High-purity (99.999\%) Ar (Argon) gas was introduced into the chamber with a total flow rate fixed at $18 \mathrm{sccm}$. The $\mathrm{ZnMnO}$ target was sputter cleaned for $20 \mathrm{~min}$ in Ar before allowing any deposition to take place on the substrate. The substrate temperature, sputter pressure, RF power and the distance between target and substrate was set at $500^{\circ} \mathrm{C}$, $5.4 \times 10^{-3}$ mbar, $250 \mathrm{~W}$ and $35 \mathrm{~mm}$, respectively.

In a second technique, $\mathrm{MnO}-\mathrm{Zn}, \mathrm{ZrO}-\mathrm{Zn}$ and $\mathrm{ZrO}-\mathrm{MnO}-\mathrm{Zn}$ coatings were deposited over mild steel $(50 \mathrm{~mm} \times 25 \mathrm{~mm} \times 1.4 \mathrm{~mm})$ substrate using pulse electrodeposition method. Zinc sheets $(90 \mathrm{~mm} \times 75 \mathrm{~mm} \times 0.8 \mathrm{~mm})$ were used as the cathode.

Substrates were polished with successive finer grade of emery papers of grades: 320,600 and 1200 followed by burnishing with a very soft cloth. The samples were then washed with tap water, cleaned in acetone using an ultrasonic bath and finally dried with air blow. Electrodeposition was then performed at $30^{\circ} \mathrm{C}$ temperature using an acidic chloride ( $\mathrm{pH} 4.3$ ).

For the composite coatings, $10 \mathrm{~g} / \mathrm{L}$ manganese and zirconium oxide particles with diameter about 40-60 nm was added into the bath. To better suspension of nanoparticles, the bath 
Table 1: Chemical composition of electrolyte bath.

\begin{tabular}{lc}
\hline Bath constituents & Chemical composition $\left(\mathrm{g} \mathrm{L}^{-1}\right)$ \\
\hline $\mathrm{ZnSO}_{4} \cdot 7 \mathrm{H}_{2} \mathrm{O}$ & 200 \\
$\mathrm{Na}_{2} \mathrm{SO}_{4}$ & 80 \\
$\mathrm{NaCl}$ & 40 \\
$\mathrm{H}_{3} \mathrm{BO}_{3}$ & 16 \\
$\mathrm{Mn}_{2} \mathrm{O}_{3}$ & 10 \\
$\mathrm{ZrO}$ & 10 \\
\hline
\end{tabular}

was stirred about $12 \mathrm{~h}$ by using a magnetic stirrer pre electrodeposition process. The concentration of various bath constituents in the electrolytic bath is presented in Table 1 .

\subsection{Sample pretreatment and corrosion tests}

The experiments were performed through accelerated corrosion tests by deploying a temperature-climate simulation chamber. The chamber was heated to $100-105^{\circ} \mathrm{C}$. The coated samples were placed in a beaker, with a capacity of $200 \mathrm{ml}$, of $3.5 \mathrm{wt}$. \% filtered sodium chloride $(\mathrm{NaCl})$ solution of which $3.5 \mathrm{~g}$ of $\mathrm{NaCl}$ was mixed in $100 \mathrm{ml}$ of deionized water.

Corrosion tests were performed in $3.5 \mathrm{wt}$. \% NaCl solution, which is appropriate for simulating corrosion due to the presence of corrosion activators (chloride ions). The beaker contained coated samples, and $\mathrm{NaCl}$ solution was placed in a heated chamber for $150 \mathrm{~h}$. The coated samples were continuously monitored, and progress was recorded after every $24 \mathrm{~h}$.

\subsection{Characterization of sputtered and electrodeposited coatings}

Structural properties of all coatings were investigated through HRXRD. The grain size of the films were estimated with Scherer's formula [24]

$$
\mathrm{D}=\mathrm{k} \lambda / \mathrm{B} \cos \theta
$$

where $\mathrm{D}$ is the grain size, $\mathrm{k}$ is the constant $(=0.9), \lambda \lambda$ is the wavelength of $\mathrm{X}$-ray $(=1.540598 \AA)$, $\mathrm{B}$ is the line width (FWHM) and $\theta$ is the Bragg angle.

Coating surface roughness values were analysed and averaged through five data points per coated sample using 3-D surface scanning interferometry. The microstructure analyses and measuring of incorporated nanoparticles weight percentage of coatings were conducted through scanning electron microscopy and energy dispersive X-ray spectroscopy (EDS), respectively.

\section{RESULTS AND DISCUSSION}

\subsection{Coating surface morphology and structure properties}

Figure 1 compares the surface morphologies of thin films manufactured by two different methods. Figure 1a shows that the film produced by sputtering method has high density and 


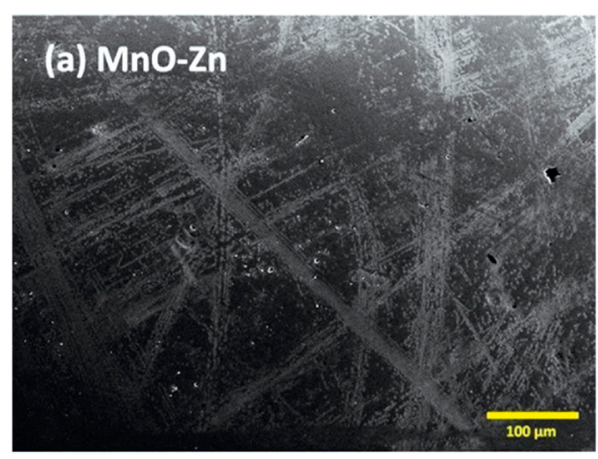

(a)

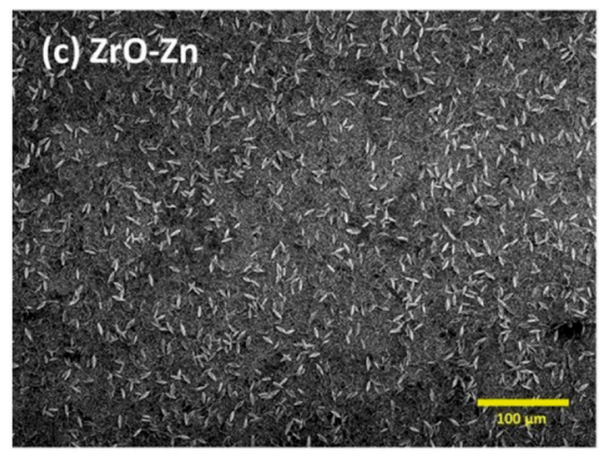

(c)

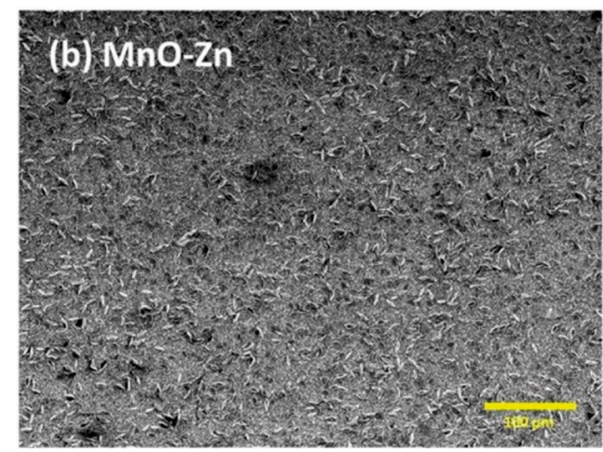

(b)

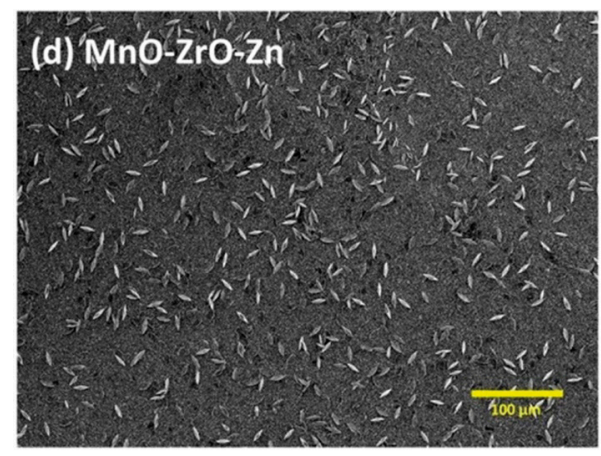

(d)

Figure 1: Micrographs of (a) sputter-deposited films and (b-d) pulse-coated films.

small value in average surface roughness $\left(\mathbf{R}_{\mathbf{a}} \sim 0.017 \mu \mathrm{m}\right)$ determined by $3 \mathrm{D}$ Interferometer. The surface morphology of electrodeposited films can be seen in Fig. 1b-d, which shows that the coating morphology consists of hexagonal platelet morphology varied from mainly granular shape to least pyramidal shapes. Similar morphology of electrodeposited Mn-Zn alloys was also reported by other researchers $[13,25,26]$.

Structural properties of both types of coatings are shown in Fig. 2. It can be seen that the sputter-deposited samples have a preferred (002) orientation, whereas pulse-coated films including $\mathrm{MnO}-\mathrm{Zn}, \mathrm{ZrO}-\mathrm{Zn}$ and $\mathrm{ZrO}-\mathrm{MnO}-\mathrm{Zn}$ have a polycrystalline structure. The varied crystallographic orientations in electrodeposited coatings cause enhanced porosity and consequently increased average surface roughness of $\mathbf{R}_{\mathbf{a}} \sim 0.39 \mu \mathrm{m}$.

The reinforcement content of nanoparticles in coatings calculated by using EDS analysis is presented in Table 2. Grain sizes in electrodeposited films are significantly small compared with those sputtered coatings. However, the porous structure of pulsed coatings is a disadvantage in terms of corrosion resistance property compared with dense sputtered films.

\subsection{Experimental set-up and corrosion study}

These experiments are the part of research being carried out in the area of corrosion within our research group [21, 27-34]. The details for the corrosion tests and sample preparation have been discussed in Section 2.2. 


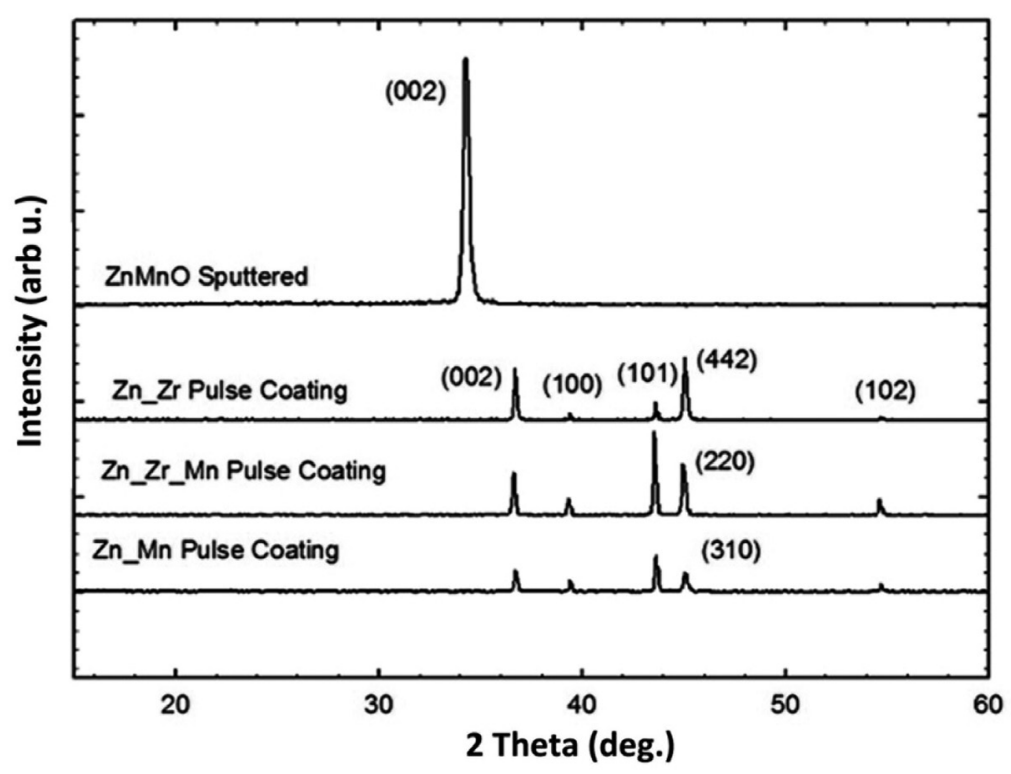

Figure 2: HRXRD patterns of sputter deposited films.

Table 2: Reinforcement content weight $\%$ of nanoparticles and grain sizes of coatings.

\begin{tabular}{llcl}
\hline Coatings & Deposition method & Grain size & Nanoparticle content wt.\% \\
\hline $\mathrm{MnO}-\mathrm{Zn}$ & Sputtered & 43.89 & $\mathrm{MnO}(14.7 \%)$ \\
$\mathrm{MnO}-\mathrm{Zn}$ & Electrodeposited & 7.69 & $\mathrm{MnO}(0.97 \%)$ \\
$\mathrm{ZrO}-\mathrm{Zn}$ & Electrodeposited & 7.51 & $\mathrm{ZrO}(1.72 \%)$ \\
$\mathrm{ZrO}-\mathrm{MnO}-\mathrm{Zn}$ & Electrodeposited & 8.71 & $\mathrm{ZrO}(2 \%), \mathrm{MnO}(1.35 \%)$ \\
\hline
\end{tabular}

The corrosion product (rust) forms on the surface of metals as a result of electrochemical reactions. The atoms on metal surface undergo changes by losing electrons and become positively charged ions. This allows them to bond to other groups of atoms that are negatively charged resulting in oxidation at anodic sites.

$$
\text { Metal } \rightarrow \text { Metal }^{\mathrm{n}+}+\mathrm{n} \text { electrons }
$$

The electrons flow from the anodic sites to cathodic sites, i.e. the electrons migrate through a metallic path. This migration occurs due to a voltage difference between the anodic and cathodic reactions. The excess of dissolved oxygen in water results in cathodic reaction and forms cathodic sites on the metal surface

$$
\mathrm{O}_{2}+2 \mathrm{H}_{2} \mathrm{O}+4 \mathrm{e}-\rightarrow 4 \mathrm{OH}-
$$

The anodic and cathodic reactions result in the formation of corrosion products (rust) on the metal surface. The metal ions $\left(\mathrm{Metal}^{\mathrm{n}+}\right)$ coming from the reaction of metal at anodic site will combine with hydroxyl ions $\left(\mathrm{OH}^{-}\right)$producing metal hydroxide.

$$
\text { Metal }^{\mathrm{n}+}+2 \mathrm{OH}^{-} \rightarrow \text { metal hydroxide }
$$


Metal hydroxide is further oxidized to form hydrated metal oxide, which is dark brown due to iron.

\subsection{Pre- and post-corrosion observations}

The possibility of occurring sputter damage is known but insufficiently investigated for corrosion products of $\mathrm{Zn}$-based steel coatings such as $\mathrm{Zn}-\mathrm{Mn}$. Post-corrosion test observations show that a compound that is formed when $\mathrm{Zn}$ and $\mathrm{Zn}$-based protection layers are exposed to a corrosive environment is $\mathrm{ZnO}$ as shown in Fig. 3. Microscopic surface analysis and comparison with pulse electrodeposited coating revealed that the distribution of corrosion products formed on the surface of sputter coating was not severe in extent as in case of electrodeposited coatings.

Table 2 shows the front face and 3-D surface images of $\mathrm{Zn}-\mathrm{Mn}, \mathrm{Zn}-\mathrm{Zr}$ and $\mathrm{Zn}-\mathrm{Zr}-\mathrm{Mn}$ coatings deposited on steel substrate. Post-corrosion test observations show that the surface morphology of the electrodeposits varied from a densely red-brown flaky rust ( $\mathrm{Zn}-\mathrm{Mn})$ to a fine white/grey ( $\mathrm{Zn}-\mathrm{Zr}-\mathrm{Mn}$ ) unstable rust, depending upon the type of alloy composition. These micrographs indicate that incorporation of a small quantity of $\mathrm{Mn}$ and $\mathrm{Zr}$ into $\mathrm{Zn}$ matrices significantly alters the corrosion morphology of the $\mathrm{Zn}-\mathrm{Mn}$ and $\mathrm{Zn}-\mathrm{Zr}-\mathrm{Mn}$ alloys. 3D scanning interferometry technique was deployed to evaluate the extent of corrosion of $\mathrm{Zn}-\mathrm{Mn}$ and $\mathrm{Zn}-\mathrm{Zr}-\mathrm{Mn}$ alloys using average surface roughness $\left(\mathbf{R}_{\mathrm{a}}\right)$ and peak surface height (PSH) as two measurement parameters. The results were analysed and compared in order to identify the coating with best corrosion resistivity.

Comparison of pre- and post-corrosion observations of $\mathrm{Zn}-\mathrm{Mn}$ sample revealed that the $\mathrm{PSH}$, after the development of rust changed from 2.94 to $109.73 \mu \mathrm{m}$. Similarly, the average surface roughness $\left(\mathbf{R}_{\mathrm{a}}\right)$ changed from 0.57 to $2.79 \mu \mathrm{m}$. Similarly, for $\mathrm{Zn}-\mathrm{Zr}$ sample, the PSH, after the development of rust changed from 3.26 to $17.54 \mu \mathrm{m}$ and the average surface roughness $\left(\mathbf{R}_{\mathrm{a}}\right)$ changed from 0.4 to $1.75 \mu \mathrm{m}$. Moreover, for $\mathrm{Zn}-\mathrm{Zr}-\mathrm{Mn}$ sample, the PSH changed from 4.31 to $9.29 \mu \mathrm{m}$ and the average surface roughness $\left(\mathbf{R}_{\mathbf{a}}\right)$ changed from 0.64 to $1.45 \mu \mathrm{m}$. The pre- and post-corrosion results for all the samples showed that PSH and $\mathrm{R}_{\mathrm{a}}$ for each
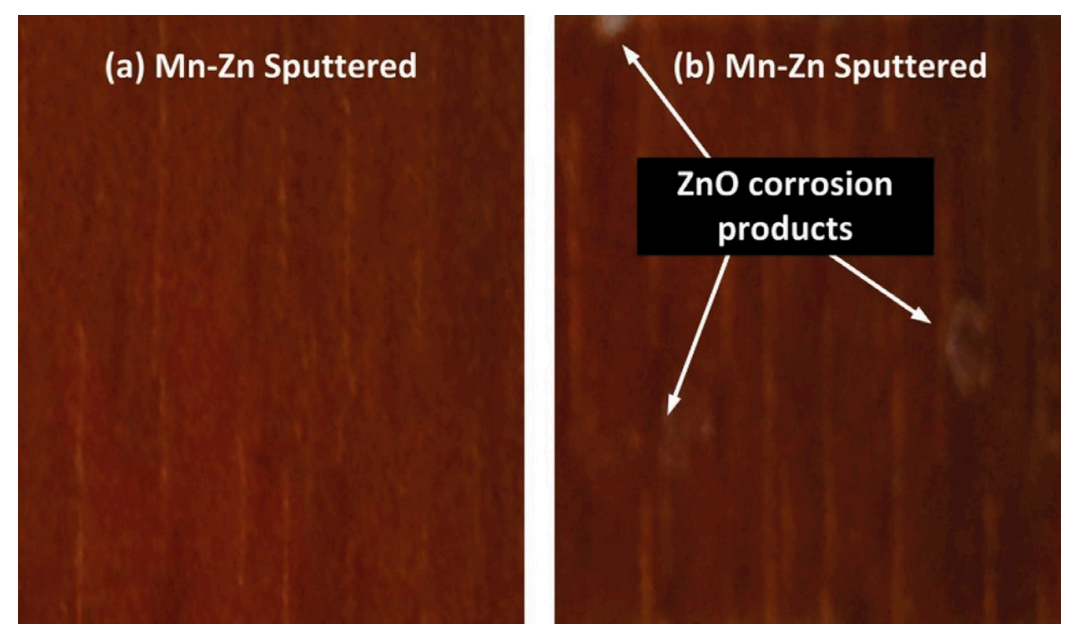

Figure 3: Samples prepared using RF sputtering technique with $\mathrm{Zn}-\mathrm{Mn}$ sputtered coating: (a) pre-test surface and (b) post-test surface. 
Table 3: Corrosion test results (pre and post) and their comparison.

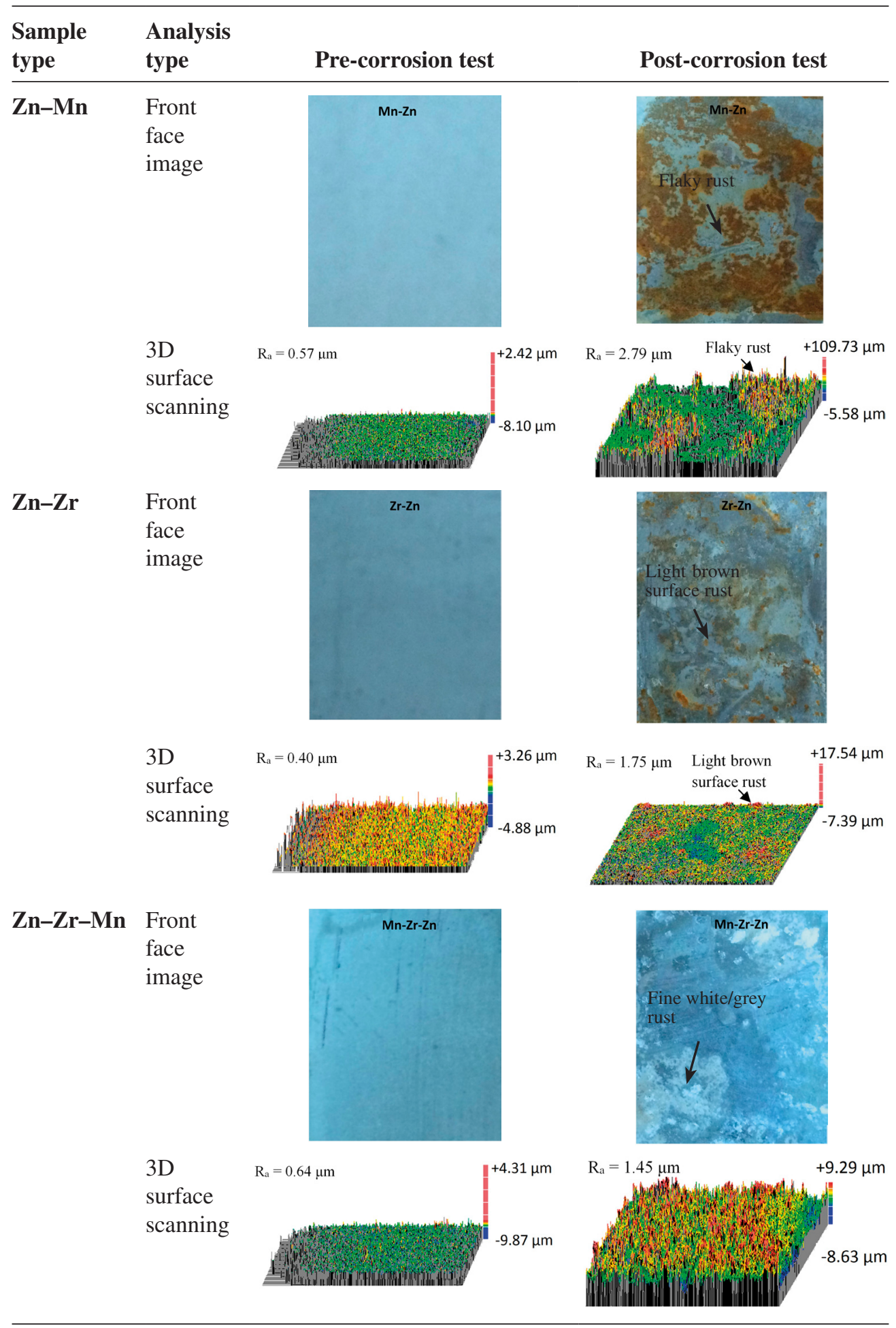


sample increased due to the development of rust, after they have been treated with $\mathrm{NaCl}$ solution. However, the highest \% increase in PSH and $\mathrm{R}_{\mathrm{a}}$ was found for $\mathrm{Zn}-\mathrm{Mn}$ while lowest was found for $\mathrm{Zn}-\mathrm{Mn}-\mathrm{Zr}$.

These results indicate that $\mathrm{Mn}$ and $\mathrm{Zr}$, both combined $(\mathrm{Zn}-\mathrm{Zr}-\mathrm{Mn})$, are the most beneficial composition, compared with individual additions of $\mathrm{Mn}$ and $\mathrm{Zr}$ into $\mathrm{Zn}$ matrices. Both $\mathrm{Mn}$ and $\mathrm{Zn}$ combined can significantly improve the resistance of the coatings to atmospheric corrosion.

\section{CONCLUSIONS}

In conclusion, $\mathrm{ZnMnO}$ thin films can be manufactured successfully by chemical and physical methods. Structural and morphological properties of the two methods (sputtering and electrodeposited) are investigated. The coating produced by sputtering method has high density and small value in average surface roughness. However, the surface morphology of electrodeposited coating consists of hexagonal platelet morphology varying from mainly granular shape to least pyramidal shapes. The varied crystallographic orientations in electrodeposited coatings cause enhanced porosity and consequently increase the average surface roughness. The corrosion tests were performed by exposing the samples (sputtered and electrodeposited) to salt solution. The purpose of the exposure was to analyse the corrosion resistance of all the samples while keeping the coating thickness constant for all three samples. The microscopic surface analysis and comparison of sputtered and pulse electrodeposited coatings revealed that the distribution of corrosion products formed on the surface of sputtered coating were not severe in extent as in case of electrodeposited coatings. For the case of electrodeposited coatings, the corrosion test results indicate that $\mathrm{Mn}$ and $\mathrm{Zr}$, both combined $(\mathrm{Zn}-\mathrm{Zr}-\mathrm{Mn})$, are the most beneficial composition, compared with individual additions of $\mathrm{Mn}$ and $\mathrm{Zr}$ into $\mathrm{Zn}$ matrices. Both $\mathrm{Mn}$ and $\mathrm{Zn}$ combined can significantly improve the resistance of the coatings to atmospheric corrosion. Also, the sputter coatings are more resistant to corrosion failures compared with electrodeposited coatings.

\section{REFERENCES}

[1] Cui, H., Ding, T., Shi, Z.L., Fang, S., Chen, G., Xu, X., Xu, C., Bottom-gate transparent zinc oxide thin film transistor fabricated by sol-gel spin coating. Nanoscience and Nanotechnology Letters, 5, pp. 209-212, 2013. doi: http://dx.doi.org/10.1166/ nnl.2013.1526

[2] Jeong, W., Kim, S. \& Park, G., Preparation and characteristic of $\mathrm{ZnO}$ thin film with high and low resistivity for an application of solar cell. Thin Solid Films, 506, pp. 180-183, 2006. doi: http://dx.doi.org/10.1016/j.tsf.2005.08.213

[3] Chen, K.-J., Hung, F.-Y., Chang, S.-J. \& Young, S.-J., Optoelectronic characteristics of UV photodetector based on $\mathrm{ZnO}$ nanowire thin films. Journal of Alloys and Compounds, 479, pp. 674-677, 2009. doi: http://dx.doi.org/10.1016/j.jallcom.2009.01.026

[4] Yoon, K.H., Choi, J.-W. \& Lee, D.-H., Characteristics of ZnO thin films deposited onto Al/Si substrates by RF magnetron sputtering. Thin Solid Films, 302, pp. 116-121, 1997. doi: http://dx.doi.org/10.1016/s0040-6090(96)09568-5

[5] Fang, T.-H., Chang, W.-J. \& Lin, C.-M., Nanoindentation characterization of ZnO thin films. Materials Science and Engineering: A, 452, pp. 715-720, 2007. doi: http:// dx.doi.org/10.1016/j.msea.2006.11.008

[6] Daniel, G.P., Justinvictor, V., Nair, P.B., Joy, K., Koshy, P. \& Thomas, P., Effect of annealing temperature on the structural and optical properties of $\mathrm{ZnO}$ thin films prepared by RF magnetron sputtering. Physica B: Condensed Matter, 405, pp. 1782-1786, 2010. doi: http://dx.doi.org/10.1016/j.physb.2010.01.039 
[7] Caglar, M., Ilican, S., Caglar, Y. \& Yakuphanoglu, F., Boron doped nanostructure ZnO films onto ITO substrate. Journal of Alloys and Compounds, 509, pp. 3177-3182, 2011. doi: http://dx.doi.org/10.1016/j.jallcom.2010.12.038

[8] Xiaotian, Y., Guotong, D., Xinqiang, W., Jinzhong, W., Boyang, L., Yuantao, Z., Dan, L., Dali, L., Ong, H.C., Shuren, Y., Effect of post-thermal annealing on properties of $\mathrm{ZnO}$ thin film grown on c- $\mathrm{Al}_{2} \mathrm{O}_{3}$ by metal-organic chemical vapor deposition. Journal of Crystal Growth, 252, pp. 275-278, 2003. doi: http://dx.doi.org/10.1016/s00220248(03)00898-4

[9] Bensmaine, S. \& Benyoucef, B., Experimental characterization of $\mathrm{ZnO}$ thins films and identification of frequency peaks in $\mathrm{ZnO} / \mathrm{SiO}_{2} \mathrm{Si} \mathrm{SAW}$ devices. American Journal of Materials Science, 3, pp. 100-103, 2013.

[10] Jin, B., Im, S. \& Lee, S., Violet and UV luminescence emitted from $\mathrm{ZnO}$ thin films grown on sapphire by pulsed laser deposition. Thin Solid Films, 366, pp. 107-110, 2000. doi: http://dx.doi.org/10.1016/s0040-6090(00)00746-x

[11] Akira, O., Takayuki, M., Kentaro, T., Yuji, M., Yusaburo, S., ZiKang T., High-throughput optimizations of alloy and doped films based on $\mathrm{ZnO}$ and parallel synthesis of $\mathrm{ZnO} / \mathrm{Mg}_{\mathrm{x}} \mathrm{ZN}_{1-\mathrm{x}} \mathrm{O}$ quantum wells using combinatorial laser MBE toward ultraviolet laser. Proc. of SPIE. The International Society for Optical Engineering: San Jose, CA, pp. 70-81, May 2000. doi: http://dx.doi.org/10.1117/12.385415

[12] Barcelo, G., Sarret, M., Müller, C. \& Pregonas, J., Corrosion resistance and mechanical properties of zinc electrocoatings. Electrochimica Acta, 43, pp. 13-20, 1998. doi: http:// dx.doi.org/10.1016/s0013-4686(97)00229-6

[13] Ganesan, S., Prabhu, G. \& Popov, B.N., Electrodeposition and characterization of $\mathrm{Zn}-\mathrm{Mn}$ coatings for corrosion protection. Surface and Coatings Technology, 238, pp. 143-151, 2014. doi: http://dx.doi.org/10.1016/j.surfcoat.2013.10.062

[14] Denham, L. \& Khan, Z., The prevention of corrosion and corrosion stress cracking on structural members of fixed deep sea oil rigs. The Journal of Corrosion Science and Engineering, 16, pp. 1-13, 2013.

[15] Dobson, P. \& Khan, Z., Design considerations for carbon steel pipes materials' selection applied in fossil powered plants subjected to wet-steam flow accelerated-corrosion review paper. Journal of Corrosion Science and Engineering JCSE, 16, pp. 1-13, 2013.

[16] Nguyen, T., Hubbard, J. \& Pommersheim, J., Unified model for the degradation of organic coatings on steel in a neutral electrolyte. Journal of Coatings Technology, 68, pp. 45-56, 1996.

[17] Prasad, T.B., Ramesh, C.S. \& Khan, Z., Experimental study on the effect of thermal barrier coating on the combustion chamber surfaces of diesel/biodiesel fuelled CI engine performance. Society of Tribologists and Lubrication Engineers Annual Meeting and Exhibition, 2013, pp. 347-350, 2013.

[18] Ramesh, C.S., Khan, S., Khan, Z. \& Sridhar, K.S., Slurry erosive wear behavior of hot extruded Al6061-Si3N4 composite. Materials Science Forum, 773-774(2014), pp. 462-468, 2013. doi: http://dx.doi.org/10.4028/www.scientific.net/msf.773-774.454

[19] Saeed, A., Khan, Z.A. \& Hadfield, M., Corrosion resistance evaluation of coatings within large vehicles through prohesion testing. ASME STLE 2012 Joint Tribology International Conference, ASME/STLE: USA, 2012.

[20] Saeed, A., Khan, Z., Hadfield, M. \& Davies, S., Material characterization and real-time wear evaluation of pistons and cylinder liners of the Tiger 131 military tank. Tribology Transactions, 56(4), pp. 637-644, 2013. doi: http://dx.doi.org/10.1080/10402004.201 3.771416 
[21] Saeed, A., Khan, Z.A. \& Montgomery, E., Corrosion damage analysis and material characterization of Sherman and Centaur - the historic military tanks. Materials Performance and Characterization, 2, pp. 1-16, 2013. doi: http://dx.doi.org/10.1520/mpc20120016

[22] Lisco, F., Abbas, A., Bowers, J.W., Claudio, G., Kaminski, P.M. \& Walls J.M., Electrodeposition of CdTe films on CdS layers deposited using magnetron sputtering and chemical bath deposition. Proc. of the 10th Photovoltaic Science, Applications and Technology Conference C96 (PVSAT-10), Holywell Park: Loughborough University, Loughborough, pp. 145-148, 23-25 April 2014.

[23] Hutchinson, J.W., Stresses and failure modes in thin films and multilayers. Lecture Notes, available at http://www.seas.harvard.edu/hutchinson/papers/462-5.pdf, 1996.

[24] Kim, Y.-S. \& Tai, W.-P., Electrical and optical properties of Al-doped ZnO thin films by sol-gel process. Applied Surface Science, 253, pp. 4911-4916, 2007. doi: http://dx.doi. org/10.1016/j.apsusc.2006.10.068

[25] Díaz-Arista, P., Ortiz, Z., Ruiz, H., Ortega, R., Meas, Y. \& Trejo, G., Electrodeposition and characterization of $\mathrm{Zn}-\mathrm{Mn}$ alloy coatings obtained from a chloride-based acidic bath containing ammonium thiocyanate as an additive. Surface and Coatings Technology, 203, pp. 1167-1175, 2009. doi: http://dx.doi.org/10.1016/j.surfcoat.2008.10.015

[26] da Silva, P.S., Schmitz, E.P.S., Spinelli, A. \& Garcia, J.R., Electrodeposition of Zn and $\mathrm{Zn}-\mathrm{Mn}$ alloy coatings from an electrolytic bath prepared by recovery of exhausted zinc-carbon batteries. Journal of Power Sources, 210, pp. 116-121, 2012. doi: http:// dx.doi.org/10.1016/j.jpowsour.2012.03.021

[27] Nazir, M.H., Khan, Z. \& Stokes, K., Modelling of metal-coating delamination incorporating variable environmental parameters. Journal of Adhesion Science and Technology, 29, pp. 1-32, 2014. doi: http://dx.doi.org/10.1080/01694243.2014.990200

[28] Nazir, M.H., Khan, Z. \& Stokes, K., Adhesive threshold predicitive modelling in the presence of interfacial impurity. Journal of Adhesion Science and Technology, submitted 2015.

[29] Nazir, M.H., Khan, Z.A. \& Stokes, K., Optimisation of interface roughness and coating thickness to maximise coating-substrate adhesion - a failure prediction and reliability assessment modelling. Journal of Adhesion Science and Technology, 29(14), pp. 14151445, 2015. doi: http://dx.doi.org/10.1080/01694243.2015.1026870

[30] Nazir, M.H., Khan, Z.A. \& Stokes, K., A holistic mathematical modelling and simulation for cathodic delamination mechanism - a novel and an efficient approach. Journal of Adhesion Science and Technology, submitted 2015.

[31] Saeed, A., Khan, Z., Clark, M., Nel, M. \& Smith, R., Non-destructive material characterisation and material loss evaluation in large historic military vehicles. Insight: Non-Destructive Testing and Condition Monitoring, 53, pp. 382-386, 2011. doi: http:// dx.doi.org/10.1784/insi.2011.53.7.382

[32] Saeed, A., Khan, Z.A., Hadfield, M. \& Davies, S., Material characterization and realtime wear evaluation of pistons and cylinder liners of the Tiger 131 Military Tank. Tribology Transactions, 56, pp. 637-644, 2013. doi: http://dx.doi.org/10.1080/104020 04.2013 .771416

[33] Nazir, M.H., Khan, Z.A. \& Stokes, K., A unified mathematical modelling and simulation for cathodic blistering mechanism incorporating diffusion and fracture mechanics concepts. Journal of Adhesion Science and Technology, 29, pp. 1-29, 2015. doi: http:// dx.doi.org/10.1080/01694243.2015.1022496

[34] Nazir, M.H., Khan, Z.A. \& Stokes, K., Maximising the interfacial toughness of thin coatings and substrate through optimisation of defined parameters. International Journal of Computational Methods \& Experimental Measurements, submitted 2015. 